ISSN 0258-7122 (Print), 2408-8293 (Online)

Bangladesh J. Agril. Res. 44(3): 553-567, September 2019

\title{
COMBINATION OF BIOLOGICAL CONTROL AGENTS AND GARLIC (ALLIUM SATIVUM) EXTRACT IN REDUCING DAMPING-OFF DISEASE OF TOMATO
}

\author{
V. O. DANIA ${ }^{1}$ AND J. A. OMIDIORA ${ }^{2}$
}

\begin{abstract}
Damping-off (Pythium aphanidermatum) is a soil-borne disease which accounts for seedling mortality and significant yield losses in tomato production. Laboratory and screenhouse experiments were conducted in 2017, with a repeated field trial in 2018 to evaluate the efficacy of combining three biological control agents (BCAs), Trichoderma viride, T. harzianum and Bacillus subtilis with Allium sativum extract for the integrated management of the disease in tomato crop. Treatments were laid out in a completely randomized design and randomized complete block design in the screenhouse and field experiments, respectively with eighteen treatments and three replications. The BCAs and extract were formulated and applied using seed treatment and soil sprinkling methods. Treatment combinations of BCAs with A. sativum were more effective in the reduction of mycelial growth of the pathogen with inhibitory values that ranged between 77.6-91.2\% than single inoculation. Seed treatment before planting was more effective than soil sprinkle method, reducing pre-emergence and damping-off incidence to between $6.8-18.3 \%$ and $9.7-26.3 \%$ under screenhouse and field conditions, respectively than the sprinkling method. Soil sprinkle with $T$. harzianum in combination with $A$. sativum extract had the highest cumulative tomato fruit yield of $902 \mathrm{~kg} / \mathrm{ha}^{-1}$ under field conditions. This study showed that combined application of BCAs and A. sativum extract reduced damping-off disease and thereby improved the fruit yield of tomato.
\end{abstract}

Keywords: Bacillus subtilis, damping-off, integrated management, Seed treatment, Soil sprinkle, Tomato

\section{Introduction}

Tomato (Solanum lycopersicum L.) is the most commonly grown and consumed vegetable worldwide (Kurze et al., 2018), because of its rich source of vitamin A and it plays an important role in maintaining the human health being a high source of lycopene which acts as an antioxidants and free radical scavenger.

Nigeria is ranked second largest producer of tomato in Africa, with an output of 1.81 million metric tonnes of tomato annually under rainfed production (Ibitoye et al., 2015). It is a food and cash crop which contributes significantly to the economy of the local population (Kator et al., 2015).

${ }^{1}$ Department of Crop Protection and Environmental Biology, University of Ibadan, PMB 001, Ibadan, Nigeria, ${ }^{2}$ International Institute of Tropical Agriculture (IITA), PMB 5320, Ibadan, Nigeria. 
The crop is propagated mainly through seeds by farmers, especially in Nigeria, that rely on their own saved seeds from previous season for planting. These helpless farmers often suffer from seed and seedling losses resulting in significant yield reduction arising from cultivation of unhealthy seeds. Among the main constraints to tomato production is the damage caused by soil-borne pathogens, mainly bacteria and fungi, which result in severe losses in production (Barone and Frusciante, 2007). Tomato plants are susceptible to many soil-borne fungal genera such as Fusarium, Rhizoctonia, Pythium and Phytophthora, causing serious diseases such as root rot, wilt and damping-off (Srinon et al., 2006).

Pre and post emergence damping-off disease of tomato is caused by Pythium aphanidermatum, a soil-borne pathogen which results in seed rot or death of young seedlings (Ashwathi et al., 2017). The pathogen can survive in the soil through the production of perennating structures such as oospores or sporangia (Agrios, 2005).

Currently, damping-off disease (Pythium aphanidermatum) of tomato is being managed in Nigeria through the use of synthetic fungicides such as Benlate. Although this approach has produced some desired results, the indiscriminate use has contributed to adverse environmental effects including reduction in beneficial soil-borne microbes and evolvement of new virulent races of pathogens (Thakur and Tripathi, 2015). The use of biocontrol agents (BCAs) in combination with other organic materials is a suitable alternative to chemical applications which ensures sustainable disease management within the concept of an integrated approach. The biocontrol agents are highly effective, inexpensive with excellent shelf life and suitable method of delivery (Someshwar et al., 2013). The antimicrobial activities of garlic, a common Nigerian spice, has been reported (Obagwu and Korsten, 2003). Botanicals are cheap, biodegradable and ecofriendly. However neither of these strategies could achieve a complete control.

Therefore, this study was designed to evaluate the effect of different formulation and combination of control options for the integrated management of dampingoff disease of tomato under screenhouse and field conditions

\section{Materials and Methods}

\section{Experimental site}

The in vitro experiment was conducted in the Plant Pathology laboratory of the Department of Crop Protection and Environmental Biology, University of Ibadan, Nigeria. The in-vivo experiments were carried out in the screen house during rainy seasons in 2017 with a repeated field trial in 2018 to validate the screenhouse results. Ibadan is located on latitude $7^{\circ} 33^{\prime} \mathrm{N} 3^{\circ} 56^{\prime} \mathrm{E}$ with an elevation of $213 \mathrm{~m}$ above sea level and annual rainfall ranging between 1250 $\mathrm{mm}$ and $1500 \mathrm{~mm}$ in the Derived savanna agroecological zone of Nigeria. 


\section{Isolation and preparation of fungal inoculum}

Pythium aphanidermatum was isolated from roots of tomato seedlings that showed damping-off symptoms such as water-soaked and shriveled stem base leading to rotting of the collar immediately above soil level. Soil debris was washed off the roots, surface-sterilized in $10 \%$ sodium hypochlorite for one minute and rinsed in three changes of sterile distilled water. Infected tissues were then cut into small sizes measuring $2 \mathrm{~mm} \times 2 \mathrm{~mm}$ washed in sterile distilled water for 1 minute and dried on sterile filter paper. Tissue samples were plated on water agar medium in $9 \mathrm{~cm}$ Petridishes and incubated at $28 \pm 2{ }^{\circ} \mathrm{C}$ for 10 days under alternating $12 \mathrm{~h}$ photoperiod of light and darkness. The fungus was then transferred to $1.7 \%$ corn meal agar (CMA) medium amended with $100 \mu \mathrm{l}$ pimaricin (Davet and Rouxel, 2000). Pathogen cultures were maintained on corn meal agar slants at $8^{\circ} \mathrm{C}$. A 3-mm diameter agar plug of mycelia was sub-cultured on a freshly prepared water agar in Petridishes and incubated in the dark at 28$30^{\circ} \mathrm{C}$ (Zamanizadeh et al., 2011). The culture plates were observed for 5 to 10 days for the development of reproductive structures such as sporangia and oospores. Identification of species was carried out using a standard monograph guide for the Pythium species (Plaats-Niterink, 1981) and following confirmation at the Mycological Herbarium at the International Institute of Tropical Agriculture, Ibadan, Nigeria.

Substrate for the growth of $P$. aphanidermatum was prepared using sorghum grains as carrier according to modified method of Khiyami et al. (2014). Grain weights of $50 \mathrm{~g}$ sorghum were poured into a 500-ml Erlenmeyer flasks, each containing $100 \mathrm{ml}$ of water. Contents of bottles were autoclaved at $121^{\circ} \mathrm{C}$ and $1.05 \mathrm{~kg} / \mathrm{cm}^{2}$ pressure for $30 \mathrm{~min}$. Excess water in the sterilized sorghum grains was drained off using sterile cheese cloth. Fungal inoculum was taken from the edge of a 7-day old culture on Potato Dextrose Agar and introduced into bottles and allowed to colonize sorghum grains for 14 days. At full mycelial ramification, the substrate in each bottle was emptied on sterile filter paper, airdried in a Laminar flow hood for two days and then ground to fine powder using a rotary blender and sieved. Sandy loam soil was sterilized at using an Sussman Electrical Sterilizer Model SG 12-04-220, USA at $71^{\circ} \mathrm{C}$ for $1 \mathrm{~h}$ prior to inoculum application at $10 \mathrm{~g} / \mathrm{kg}$ of sterilized soil (Adandonon et al., 2006).

\section{Isolation and formulation of biological control agents}

Trichoderma species were isolated from tomato rhizosphere from four different locations using serial dilution method. Ten grammes of soil adhering to roots of each sample were dissolved in $100 \mathrm{ml}$ of sterile distilled water, shaken for 20 minutes on a rotary shaker, and diluted serially in sterile distilled water. One $\mathrm{ml}$ from each of $10^{-4}$ to $10^{-6}$ dilutions was dispensed on acidified potato dextrose agar with ten replicates and incubated at $28 \pm 2^{\circ} \mathrm{C}$ for 3 days. Selected cultures 
with typical green Trichoderma colonies were purified and identified using standard taxonomical keys for Trichoderma (Rifai, 1969, Bissett, 1991). Mass production of Trichoderma species was carried out using modified Richards medium (Harman et al., 1991) which contained $10 \mathrm{~g} \mathrm{KNO}_{3}, 5 \mathrm{~g} \mathrm{KH}_{2} \mathrm{PO}_{4}, 1.3 \mathrm{~g}$ anhydrous $\mathrm{MgSO}_{4}, 8 \mathrm{~g}$ sucrose, $20 \mathrm{mg} \mathrm{FeCl}$ and $100 \mathrm{ml}$ of tomato juice in 1 litre of sterile distilled water. An aliquot of $100 \mathrm{ml}$ of the medium was dispensed in 250- $\mathrm{ml}$ conical flask and inoculated with a 5-mm agar plug from a 7-day-old culture on acidified potato agar medium and incubated at $28 \pm 2{ }^{\circ} \mathrm{C}$. After 21 days incubation period, the mycelia were harvested and air-dried in plastic plates under sterile conditions at room temperature $\left(28-30^{\circ} \mathrm{C}\right)$ for two days. They were thereafter ground to a fine powder in a blender and stored at $4^{\circ} \mathrm{C}$ in polyethylene bags until it was required for the study. Colony forming units in formulation of Trichoderma spp. mixtures was adjusted to $3 \times 10^{7} \mathrm{cfu} / \mathrm{g}$ (Nashwal et al., 2008). A powder formulation of Bacillus subtilis containing $10^{8}$ colony forming units per gram $\left(\mathrm{cfu} / \mathrm{g}^{-1}\right)$ used in this experiment was collected from the Microbiology unit of the International Institute of Tropical Agriculture, Ibadan, Nigeria.

Inhibitory effect of biological control agents and Allium sativum extract on radial mycelial growth of Pythium aphanidermatum in vitro

Fresh healthy bulbs of $A$. sativum were washed with sterile distilled water (SDW) and ground to a fine pulp using a rotary blender MJ-BL 40G1 JA. Four samples of $50 \mathrm{~g}, 100 \mathrm{~g}, 200 \mathrm{~g}$ and $250 \mathrm{~g}$ were weighed separately. The weights were ground to a pulp of each sample weight and dissolved in 1litre of SDW to produce final extract concentrations of $5 \%, 10 \%, 20 \%$ and $25 \% \mathrm{w} / \mathrm{v}$, respectively. The extract suspensions were agitated intermittently for 10 minutes and left in the Laminar flow hood overnight to enable the active constituents dissolve in the medium. The suspension was then filtered through sterile cheese cloth into Erlenmeyer flask. An aliquot of $1 \mathrm{ml}$ was dispensed into $15 \mathrm{ml}$ acidified PDA in $9 \mathrm{~cm}$ diameter Petridishes and swirled gently to allow proper mixing of extract and medium. After solidification of the PDA, a 3-mm cork borer was used to obtain mycelial disc from the edge of 7-day old colonies of $P$. aphanidermatum and placed at the centre of each Petridish. Biological control agents, $T$. viride, $T$. harzianum and B. subtilis were inoculated at four equidistant points relative to the pathogen at the center of each Petridish. The control consisted of the pathogen grown on unamended PDA. While a synthetic mancozeb fungicide applied at the rate of $0.5 \mathrm{~g} / \mathrm{l}$ served as positive check. Each concentration consisted of four replicates in a completely randomized design with 19 treatments. Petridishes were incubated at $28 \pm 2^{\circ} \mathrm{C}$ and the radial growth of the colony treatment was measured at 5 days of incubation and expressed as a percentage of the control. 


\section{Screenhouse and field evaluation of effect of single and combined application of Allium sativum extract and biological control agents on incidence of damping-off disease}

Healthy seeds of a susceptible tomato variety UC82B used in this experiment were obtained from a certified agricultural commercial seed center in Ibadan, Nigeria. Treatments were applied using two methods i.e. seed treatment and soil sprinkle (Harman et al., 1991). The seeds were slightly moistened with sterile distilled water and then treated with the powdered formulation of Trichoderma species and B. subtilis with spore concentration of $3 \times 10^{7} \mathrm{cfu} / \mathrm{g}^{-1}$ and $10^{8} \mathrm{cfu} / \mathrm{g}^{-1}$ respectively as previously described, at the rate of $10 \mathrm{~g} / \mathrm{kg}$ seeds. Sterilized starch was added to the powdered seed mixture at $5 \mathrm{~g} / \mathrm{kg}$ as adhesive and mixed thoroughly in aseptic plastic bowls before being planted in soil artificially inoculated with the pathogen at $10 \mathrm{~g} / \mathrm{kg}$ of soil 2 days before planting. In the seed treatment with the extract, a $25 \% \mathrm{w} / \mathrm{v}$ A. sativum concentration which proved to be most effective in the in vitro trial was selected and used in the screenhouse and field experiments. It involved soaking the tomato seeds in the extract solution for 10 minutes. The seeds were then air-dried at room temperature $\left(28 \pm 2^{\circ} \mathrm{C}\right)$ for $1 \mathrm{~h}$ before planting. Soil inoculation with $P$. aphanidermatum was done at $10 \mathrm{~g} / \mathrm{kg}$ of sterilized soil as previously described. The soil sprinkle method involved mixing of $0.5 \mathrm{~g}$ powdered formulation of BCAs with $5 \mathrm{~g}$ of sterilized soil and sprinkling of the mixture in each planting hole. Experimental pots measuring $25 \mathrm{~cm}$ in diameter were each filled at $90 \%$ capacity with $5 \mathrm{~kg}$ sandy loam soil sterilized using a Sussman Electrical Sterilizer Model SG 12-04220 , USA at $71^{\circ} \mathrm{C}$ for 2 hours. Four seeds were planted per pot which were later thinned to two and the experimental layout was a randomized complete design with three replications. Screen house environmental conditions varied between $74 \pm 2 \%$ to $90 \pm 2 \%$ relative humidity with a temperature range of $28 \pm 2^{\circ} \mathrm{C}$. The experiment consisted of 18 treatment combinations: $\mathrm{T}_{1}=$ Trichoderma viride seed treatment, $\mathrm{T}_{2}=$ Trichoderma viride soil sprinkle, $\mathrm{T}_{3}=$ Trichoderma harzianum seed treatment, $\mathrm{T}_{4}=$ Trichoderma harzianum soil sprinkle, $\mathrm{T}_{5}=$ Bacillus subtilis seed treatment, $\mathrm{T}_{6}=$ Bacillus subtilis soil sprinkle, $\mathrm{T}_{7}=$ Allium sativum seed treatment, $\mathrm{T}_{8}=$ Allium sativum soil sprinkle, $\mathrm{T}_{9}=$ Trichoderma viride seed treatment $+25 \%$ A. sativum, $\mathrm{T}_{10}=$ Trichoderma viride soil sprinkle $+25 \%$ A. sativum, $\mathrm{T}_{11}=T$. harzianum seed treatment $+25 \%$ A. sativum, $\mathrm{T}_{12}=T$. harzianum soil sprinkle + $25 \%$ A. sativum, $\mathrm{T}_{13}=$ Bacillus subtilis seed treatment $+25 \%$ A. sativum, $\mathrm{T}_{14}=$ Bacillus subtilis soil sprinkle $+25 \%$ A. sativum, $\mathrm{T}_{15}=$ Inoculated and untreated, $\mathrm{T}_{16}=$ Uninoculated and untreated, $\mathrm{T}_{17}=$ Mancozeb seed treatment and $\mathrm{T}_{18}=$ Mancozeb soil sprinkle.

The percentage of pre-emergence and post emergence damping-off were recorded weekly and calculated:

Pre-emergence damping-off $=\frac{\text { No.of ungerminated seeds }}{\text { Totalnumber of plantedseeds }} \times \frac{100}{1}$ 
Post-emergence damping-off $=\frac{\text { No.of infectedseedlings }}{\text { Totalnumber of germinatedseedlings }} \times \frac{100}{1}$

The effect of treatment combinations on growth and yield parameters were determined according to Khiyami et al. (2014). Disease incidence was calculated by expressing the number of symptomatic plants as a percentage of the total plants evaluated. Disease control was calculated and expressed as a percentage:

Disease control $=[1-\mathrm{DT} / \mathrm{DC}] \times 100$

Where DR $=$ Disease reduction, DT $=$ Disease incidence on treatment

$\mathrm{DC}=$ Disease incidence on control.

Disease severity rating was evaluated on a scale of 1-5 using the modified method of Adandonon et al. (2006):

$1=$ No symptoms, $2=$ No wilting of leaves, seedlings fell on the ground after fourth day, $3=$ Wilting of leaves on $3^{\text {rd }}$ day with plants falling to the ground on fourth day, $4=$ Wilting of leaves on third day with plants falling on ground same day, $5=$ Wilting of leaves on second day with seedlings falling to the ground same day or next day. $6=$ Wilting of leaves on first day with seedlings falling over on second day.

Disease severity values obtained were converted to percentages using the method os Assad et al. (2010):

Disease severity $=\frac{\text { Sum of disease ratings }}{\text { Totalnumber of ratings }} \times \frac{100}{\text { Maximum disease grade }}$

The field experiment was conducted in 2018 to validate results obtained in the screenhouse in 2017 at the University Teaching and Research Farm, Ibadan, Nigeria. Therefore, the same treatments that were used in the screenhouse were also evaluated in the field trials. However, the experiment was conducted under natural conditions in a planting site with history of damping -off disease. Each plot was $3 \times 3 \mathrm{~m}$ in area with three rows of $3 \mathrm{~m}$ in length and $50 \mathrm{~cm}$ in width. The trial consisted of plots (treatments) in a randomized complete block design with three replications. Four tomato seeds were planted per hole at a spacing of $60 \mathrm{~cm}$ $\times 50 \mathrm{~cm}$ which were later thinned to two. All parameters that were assessed in the screenhouse experiment were also evaluated in the field. Seed-to-plant transmission of damping off disease was evaluated by planting seeds harvested from control plants in the previous screenhouse experiment that were inoculated with $P$. aphanidermatum but untreated. Seeds that were harvested from uninoculated plants served as control. Data collected included percentage preand, post-emergence damping-off, and seedling mortality as described above.

Plant growth parameters such as plant height, number of leaves per plant, stem diameter, fresh weight of plant, and yield were determined according to Abd-ElKhair et al. (2010). 


\section{Statistical analysis}

Data were subjected to analysis of variance (ANOVA) using the general linear model (GLM) procedure of the Statistical Analysis System Version 9.1, Institute (SAS institute Inc., 2002). ANOVA was made by $\mathrm{F}$ variance test and the pair comparisons were done by Duncan's Multiple Range Test (DMRT) at $\mathrm{P}=0.05$.

\section{Results and Discussion}

The inoculation of individual biological control agent reduced radial mycelial growth of $P$. aphanidermatum to between $64.8-67.2 \%$ (Table 1). Similarly, the four extract concentrations of $A$. sativum evaluated also had inhibitory effect on growth of the test pathogen varying from 54.2-67.3\% relative to the control which was neither amended with BCA nor extract with $100 \%$ growth and no inhibition. However, the efficacy of the extract increased with concentration, being most effective at $25 \% \mathrm{w} / \mathrm{v}$. Generally, treatment combinations of BCAs with $A$. sativum proved to be more effective in the reduction of mycelial growth of the pathogen with inhibitory values that ranged between 77.6-91.2\%. Their effects were significantly higher than those of single inoculation of individual BCA or extract against the pathogen.

Table 1. Inhibitory effect of Allium sativum extract combinations with BCAs on mycelia growth of $P$. aphanidermatum in-vitro

\begin{tabular}{lcc}
\hline \multicolumn{1}{c}{ Treatment } & Mycelial growth (mm) & Reduction (\%) \\
\hline Pathogen alone & $100 \mathrm{a}$ & $0.0 \mathrm{c}$ \\
Pathogen + T. viride & $34.8 \mathrm{bc}$ & $65.2 \mathrm{bc}$ \\
Pathogen + T. harzianum & $32.8 \mathrm{bc}$ & $67.2 \mathrm{~b}$ \\
Pathogen + B. subtilis & $39.2 \mathrm{~b}$ & $64.8 \mathrm{bc}$ \\
Pathogen $+5 \%$ A. sativum & $45.8 \mathrm{ab}$ & $54.2 \mathrm{c}$ \\
Pathogen $+10 \%$ A. sativum & $41.2 \mathrm{~b}$ & $58.8 \mathrm{c}$ \\
Pathogen $+20 \%$ A. sativum & $34.8 \mathrm{bc}$ & $65.2 \mathrm{bc}$ \\
Pathogen $+25 \%$ A. sativum & $32.7 \mathrm{bc}$ & $67.3 \mathrm{~b}$ \\
Pathogen + T. viride $+5 \%$ A. sativum & $22.4 \mathrm{~cd}$ & $77.6 \mathrm{ab}$ \\
Pathogen + T. viride $+10 \%$ A. sativum & $13.5 \mathrm{~d}$ & $86.5 \mathrm{a}$ \\
Pathogen + T. viride $+20 \%$ A. sativum & $11.7 \mathrm{~d}$ & $88.3 \mathrm{a}$ \\
Pathogen + T. viride $+25 \%$ A. sativum & $12.3 \mathrm{~d}$ & $87.7 \mathrm{a}$ \\
Pathogen + T. harzianum $+5 \%$ A. sativum & $19.1 \mathrm{~cd}$ & $80.9 \mathrm{ab}$ \\
Pathogen + T. harzianum $+10 \%$ A. sativum & $10.3 \mathrm{de}$ & $89.7 \mathrm{a}$ \\
Pathogen + T. harzianum $+20 \%$ A. sativum & $13.2 \mathrm{~d}$ & $86.8 \mathrm{a}$ \\
Pathogen + T. harzianum+ 25\% A. sativum & $8.8 \mathrm{de}$ & $91.2 \mathrm{a}$ \\
Pathogen + B. subtilis $+5 \%$ A. sativum & $32.2 \mathrm{bc}$ & $67.8 \mathrm{~b}$ \\
Pathogen + B. subtilis $+10 \%$ A. sativum & $27.1 \mathrm{c}$ & $72.9 \mathrm{~b}$ \\
Pathogen + B. subtilis $+20 \%$ A. sativum & $20.4 \mathrm{~cd}$ & $79.6 \mathrm{ab}$ \\
Pathogen + B. subtilis $+25 \%$ A. sativum & $18.1 \mathrm{~cd}$ & $81.9 \mathrm{ab}$ \\
Pathogen + Mancozeb & $9.6 \mathrm{dde}$ & $90.1 \mathrm{a}$ \\
\hline
\end{tabular}

Means with same letters along a column are not significantly different using DMRT test at $\mathrm{P}=0.05$. 
However, inoculation of T. harzianum in combination with $25 \% \mathrm{w} / \mathrm{v}$ A. sativum concentration had significantly higher inhibition of the the test pathogen than other treatments and control. In contrast, inoculation of B. subtilis in the dual culture was least effective among the BCAs. All the BCAs significantly $(\mathrm{P}<0.05)$ inhibited radial mycelial growth of $P$. aphanidermatum when applied either singly or in combination with varying concentrations of A. sativum in the in vitro trial compared to the control. This result was consistent with the findings of Idowu et al. (2016) who reported the ability of Trichoderma species to inhibit Pythium spp, causing damping-off disease in seedlings of sweet pepper variety. A zone of inhibition was observed between $B$. subtilis and the pathogen with an apparent lysis of the pathogen mycelia, which may have been due to the production of metabolites or antibiotics by the BCA (Demoz and Korsten, 2006); while Trichoderma spp. grew on the mycelia of the test pathogen, under microscopic examination suggesting that the mode of control by the BCAs could be hyper parasitism (Howell, 2003; Harman et al,. 2004). Allium sativum extract also reduced mycelial growth of the test pathogen, but was more effective when applied in combination with the BCAs. Its inhibitory action may be due to its active ingredient 'allicin', which enhances its potency against plant pathogens (Obagwu and Korsten, 2003).

Screenhouse and Field evaluation of single and combined application of $A$. sativum leaf extract and Biological control agents on incidence of dampingoff disease

Tomato seeds that were treated with inoculum powder of either the BCA or extract alone had better inhibitory effect on the test pathogen than the control in the screenhouse experiment of 2017 and the repeated field experiment in 2018 (Table 2). Seed treatment before planting was more effective than soil sprinkle method, reducing pre-emergence damping off incidence to between $6.8-18.3 \%$ and 9.7-26.3\% under screenhouse and field conditions respectively. Treatment of tomato seeds with $T$. harzianum in combination with A. sativum extract proved to be most effective in the single application of the BCAs with a pre and post emergence disease reduction. In contrast, the application of B. subtilis either as seed treatment or soil sprinkle was least effective among the BCAs in overall disease incidence, severity and control. Although single dosages of the BCAs and A. sativum extract significantly $(\mathrm{P}<0.05)$ reduced damping-off disease, better results were obtained with the treatment combinations. Seeds that were treated with a mixture of $\mathrm{BCA}$ and $A$. sativum extract significantly $(\mathrm{P}<0.05)$ reduced disease incidence relative to single treatments and compared well to mancozeb fungicide. 


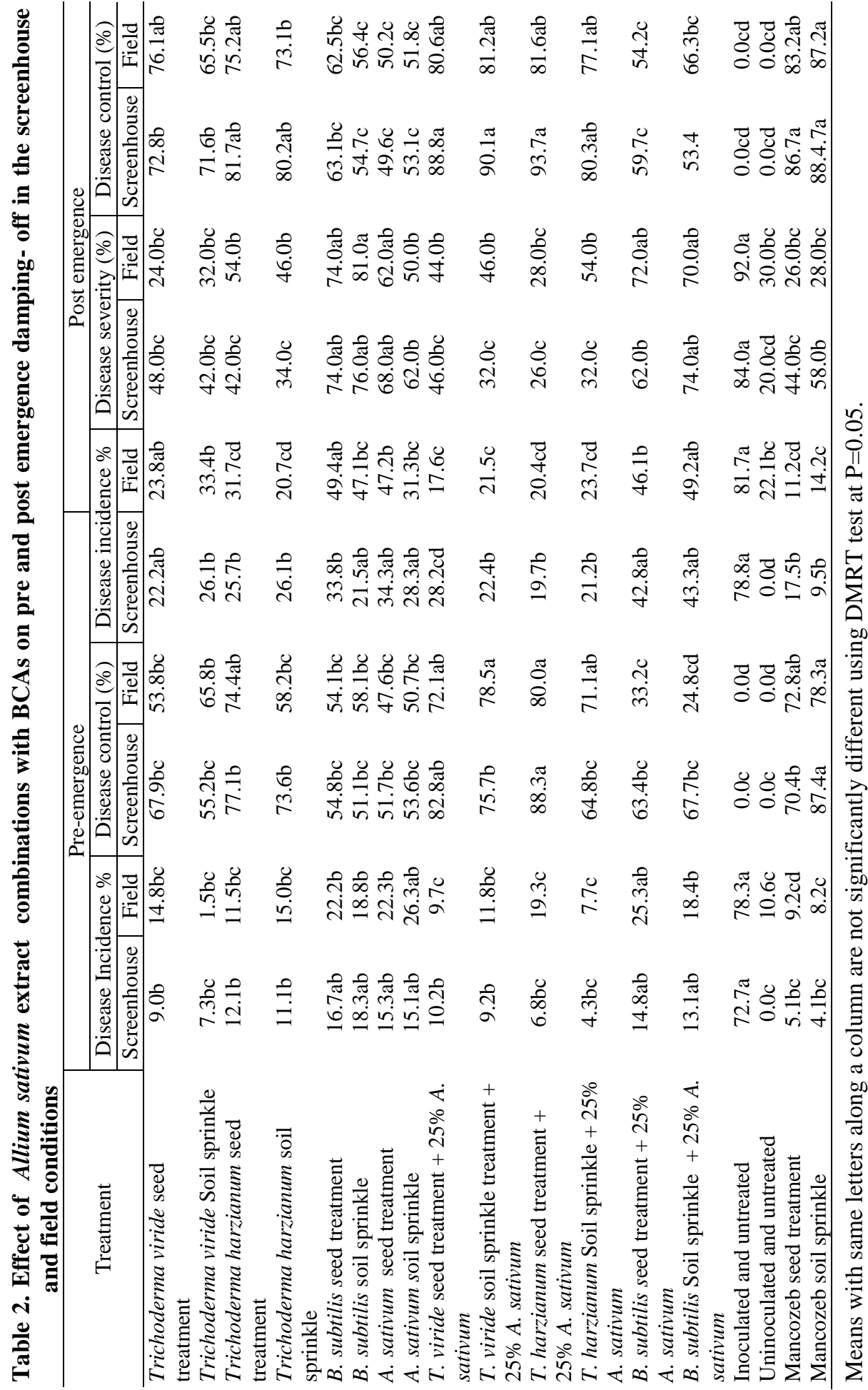


These results agree with the earlier report of Adanonon et al. (2006) that found seed treatment with BCAs to be more effective than using the soil drench method in the control of soil-bone Sclerotium rolfsii. Also, Trichoderma spp. used as seed treatment was reported to significantly reduce the incidence of damping-off disease than other formulation methods (Idowu et al., 2016). Disease incidence was apparently higher under field conditions than in the screenhouse. The better disease control achieved in the screenhouse may be due to the asepetic condition that was maintained in the screenhouse which included sterilization of soil that was used in planting and the controlled environment. On the contrary, the environmental conditions could not be regulated in the field, where planting was also done without soil sterilization under natural conditions. However, under field conditions, it was observed that some of the uninoculated and untreated plants were symptomatic, although with a comparatively lower disease incidence. Disease incidence and severity were significantly $(\mathrm{P}<0.05)$ lower in case of treatment combinations than single treatment dosage and untreated control. The application of the treatment combination as seed treatment was generally more effective than the sprinkle method in reducing both incidence and of disease severity. Seed treatment with $T$. harzianum in combination with A. sativum extract had significantly $(\mathrm{P}<0.05$ lower incidence when compared to other treatments and the untreated control.

Trichoderma harzianum when applied in combination with $25 \%$ w/v concentration of A. sativum extract was most effective in reducing damping-off incidence, severity and control. Several reports had corroborated the efficacy of T. harzianum in the control of soil-borne pathogens (Howell 2003; Manjula et al., 2005; Kumari et al., 2015). In contrast, Bacillus subtilis was least effective among the BCAs in disease control both in the screenhouse and field. While Trichoderma spp. are fortified with several methods of pathogen control such as rapid competition and colonization of substrate, hyperparasitism and production of lytic enzymes, B. subtilis rely mainly on the mechanism of antibiosis (Dania et al., 2016).

All treatments and their combinations significantly $(\mathrm{P}<0.05)$ influenced plant height and stem diameter both in the screenhouse and field trials (Table 3). However, tomato plants that were planted under field conditions had significantly higher shoot weight, number of leaves and fruit yield than those grown in the screenhouse. These might be due to the inability of the tomato plant roots in the screenhouse to expand fully due to the reduced space in each experimental pot, hence limited access to nutrients which ultimately influenced the overall yield compared to those that were planted in the open and unrestricted field (Muriungi et al., 2014). 


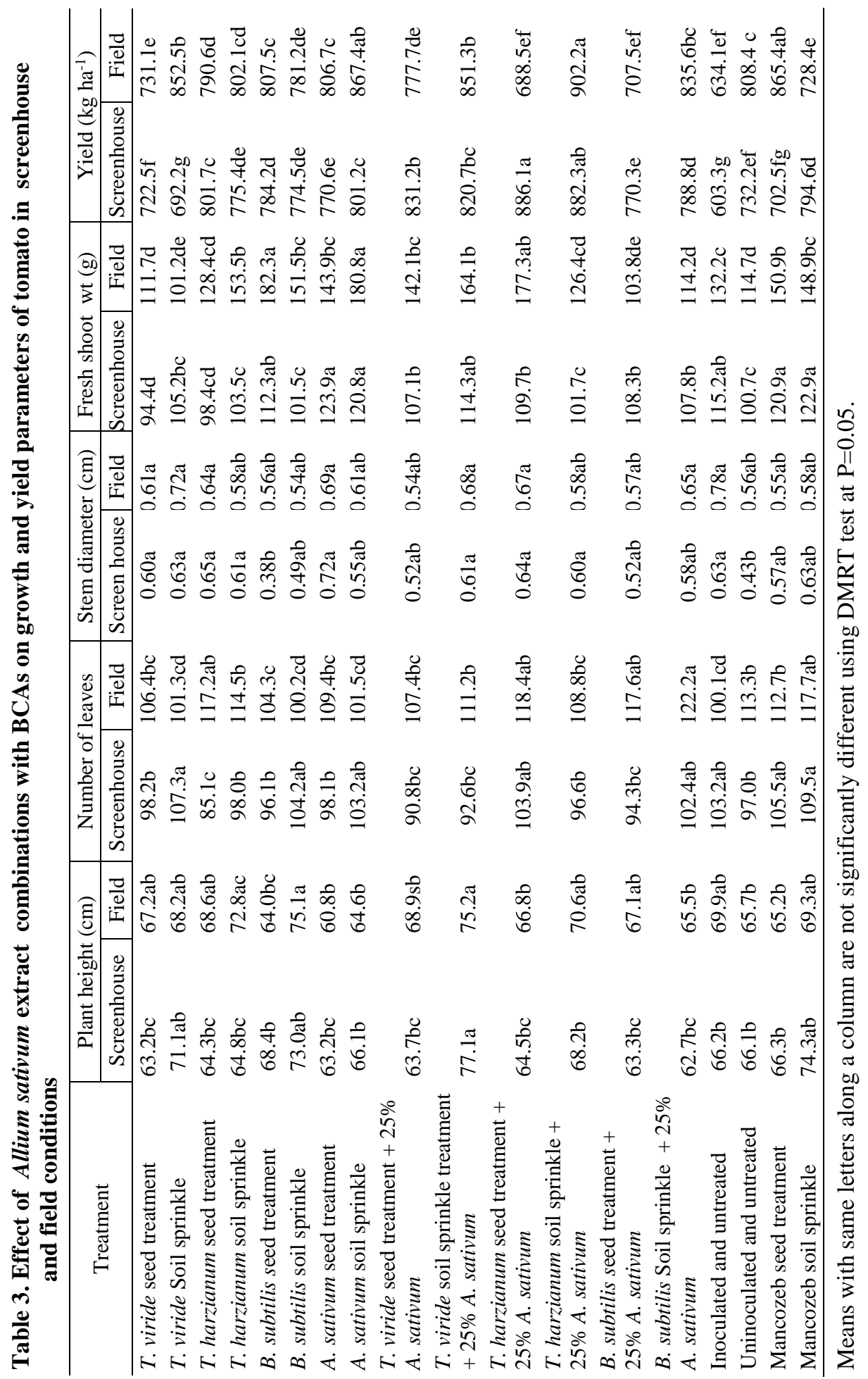




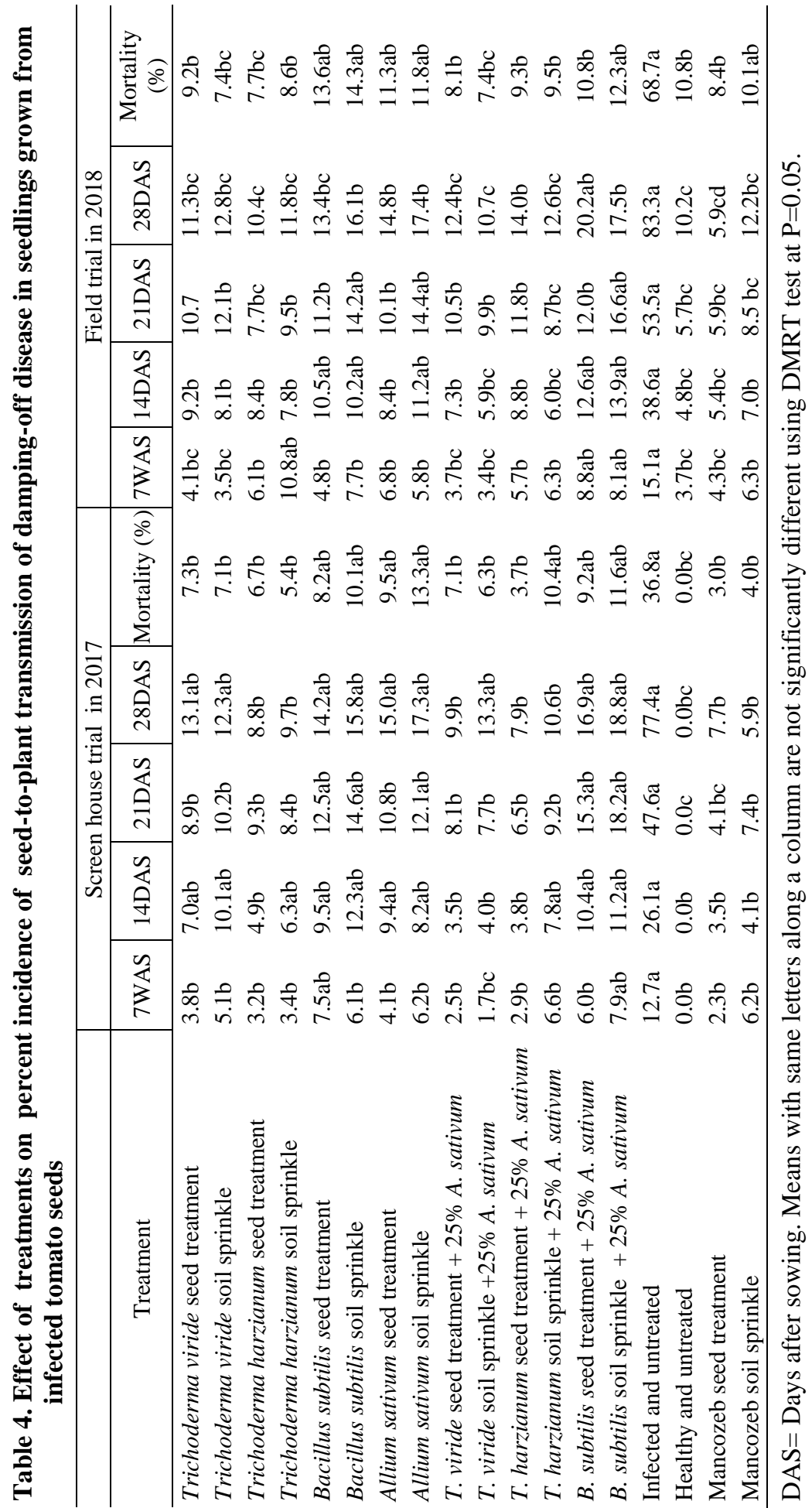


Soil sprinkle with $T$. harzianum in combination with A. sativum extract had the highest cumulative tomato yield of $902 \mathrm{~kg} / \mathrm{ha}^{-1}$ under field conditions. Fruit yield was significantly higher in plots that were treated with either BCAs or extract alone and their combinations than those of inoculated but untreated that served as control. The inherent ability of Trichoderma harzianum to reduce disease incidence of several pathogens by stimulating vegetative growth and enhancing root development and overall yield of the treated plants were also reported (Harman et al., 2004; Singh and Singh, 2004).

The application of treatments reduced the incidence of seed-to-plant transmission of damping-off disease among seeds that were inoculated before planting (Table 4). Seed-to-plant transmission was reduced to between $7.9-18.8 \%$ and 10.2$20.2 \%$ in screenhouse and field trials respectively relative to control. Similarly, the treatment combinations reduced seedling mortality better than individual application at 28 days after inoculation.

Disease incidence was significantly lower among plants that were inoculated and treated with combinations of BCAs and A. sativum extract than control plants in both trials. Also, seedling mortality was significantly reduced $(\mathrm{P}<0.05)$ among the treatments compared to control. However, seedling mortality was comparatively higher under field conditions than the screenhouse. Healthy seeds that were uninoculated and untreated were asymptomatic in the screenhouse; however, some of the emerging seedlings became symptomatic under field condition.The combination of biological control agents with Allium sativum extract significantly reduced the incidence, severity and seedling mortality caused by damping-off disease. Therefore, the treatment combination as shown in this study could be explored to reduce annual seedlings and yield losses due to the damping-off disease among tomato farmers in Nigeria.

\section{References}

Abd-El-Khair , H., R. Kh. M. Khalifa and H.E.H. Karima, 2010. Effect of Trichoderma species on damping off diseases incidence,some plant enzymes activity and nutritional status of bean plants. Amer. J. Sci. 6(9):486-497.

Adandonon, A., T.A.S. Aveling, N. Labuschagne and M. Tamo. 2006. Biocontrol agents in combination with Moringa oleifera extract for integrated control of Sclerotiumcaused cowpea damping-off and stem rot. European J. Plant Pathol. 115(4):409418.DOI 10.1007/s10658-006-9031-6

Agrios, GN. 2005. Plant Pathology, 5th Edition. Academic Press, Inc., San Diego, USA. 922pp.

Asad, M., S. Shafqat, I. Naeem, T.M. Muhammed and R.K. Munawer. 2010. Methodology for the evaluation of symptoms severity of mango sudden death syndrome in Pakistan. Pakistan J. Bot. 42 (2):1289-1299.

Ashwathi, S., C. Ushamalini, S. Parthasarathy and S. Nakkeeran. 2017. Morphological, pathogenic and molecular characterisation of Pythium aphanidermatum: A causal pathogen of coriander damping-off in India. The Pharm. Innovation J. 6(11): 44-48 
Barone, A. and L. Frusciante . 2007. Molecular marker-assisted selection for resistance to pathogens in tomato, Marker-Assisted Selection, Current status and future perspectives in crops, livestock, forestry and fish. pp. 153- 164.

Bissett, J. 1991. A revision of the genus Trichoderma II Infrageneric classification. Canadian J. Botany 69:2357-2372.

Dania, V.O., O.O. Fadina, M. Ayodele and P. Lava Kumar . 2016. Evaluation of isolates of Trichoderma, Pseudomonas and Bacillus species as treatment for the control of post-harvest fungal rot disease of yam (Dioscorea spp.). Archives of Phytopathol. and Plant Prot. 49(15-16): 1-15.

Davet, P. F. and F. Rouxel. 2000. Detection and isolation of soil fungi. Science Publishers Inc, $4^{\text {th }}$ Edition Enfield, USA. 188pp.

Demoz, B.T. and L. Korsten. 2006. Bacillus subtilis attachment, colonization and survival on avocado flowers and its mode of action on stem end-rot pathogens. Biological Contr. 37:86-74.

Harman , G. E., C.R. Howell, A. Viterbo, I. Chet and M. Lorito. 2004. Trichoderma species opportunistic, avirulent plant symbionts. Nature Rev. Microbiol. 2:43-56.

Harman, GE., Stasz, T.E. Peruzzotti, A.C. Leopold, and A.G.Taylor. 991. Production of Conidial Biomass of Trichoderma harzianum for Biological Control. Biol. Contr. 1: 23-28.

Howell, C.R., 2003. Mechanisms employed by Trichoderma species in the biological control of plant diseases: The history and evolution of current concepts. Plant Dis. 87:4-10.

Ibitoye, S.J., U.M. Shaibu and B. Omole. 2015. Analysis of Resource Use Efficiency in Tomato (Solanum lycopersicum) Production in Kogi State, Nigeria. Asian J. Agric. Ext., Economics and Sociol. 6(4): 220-229.

Idowu, O.O., A.C. Oni and A.O. Salami. 2016. The interactive effects of three Trichoderma species and damping-off causative pathogen Pythium aphanidermatum on emergence indices, infection incidence and growth performance of sweet pepper. Int. J. Recent Scientific Res. 7 (4):10339-10347.

Kator, L., D.O. Onah and Y.H. Zakki. 2015. Incidence and Severity of Sclerotium rolfsii disease on Tomato Farms in Chile Island (Makurdi), Benue State, Nigeria. IOSR J. Agric. and Veterinary Sci. (IOSR-JAVS). 8(11) 97-103. DOI: 10.9790/23800811297103

Kurze, E., R. Lo Scalzo, G. Campanelli and P. Schwab. 2018. Effect of tomato variety, cultivation, climate and processing on Sola 14 , an allergen from Solanum $\begin{array}{llll}\text { lycopersicum. } & \text { Plos } & \text { one } & \text { 13(6): }\end{array}$ https://doi.org/10.1371/journal.pone.0197971

Khiyami, M.A., M.R. Omar, K.A. Abd-Elsalam and A. Abd El-Hady. 2014. Bacillusbased biological control of cotton seedling disease complex. J. Plant Protect. Res. 54 (4):341-348.

Kumari, T.G.V., K. Basu, T.G. Nithya, A.Varma and A. C. Kharkwal. 2015. Study of Bio-efficacy of Alkali tolerant Trichoderma against damping off and rotting diseases of Tomato and Cauliflower caused by Pythium spp. and Sclerotina spp. Int. J. ChemTech Res. 8(6):628-634. 
Manjula K., M. Mwangi and R. Bandyopadhyay. 2005. Potentials of some bacteria and fungi as biocontrol agents of cassava and yam under laboratory and green house conditions. Afr.

Crop Sci. Proc. 7:395-1400.

Muriungi, S.J., E.W. Mutitu and J.W. Muthomi. 2014. Efficacy of cultural methods in the control of Rhizoctonia solani strains causing tomato damping- off in Kenya. Afri. J. Food, Agric., Nutrition and Dev. 14(2):8776-8789.

Nashwal, M.A., K.A.M. Sallam, M.A.E. Abo-Elyousr and M. Hassan. 2008. Evaluation of Trichoderma species as Biocontrol Agents for Damping-off and Wilt Diseases of Phaseolus vulgaris L. and Efficacy of Suggested Formula. Egyptian J. Phytopathol. 36 (1-2):81-93

Obagwu, J. and L. Korsten. 2003. Control of citrus green and blue moulds with garlic extracts. Eur. J. Plant Pathol.109:221-225

Plaats-Niterink, A. J. 1981. Monograph of the genus Pythium. studies in mycology, No. 21. Centraal bureau Voor Schimmelcultures, Baarn, Netherlands pp 21:1-244

Rifai, M.A. 1969. A revision of the genus Trichoderma. Mycological Papers 116: 1-56.

SAS Institute 2002. SAS/STAT. Guide for personal computers, version 9.1 edition. SAS Institute, Cary, NC pp 115-125

Singh, A. and H.B. Singh. 2004. Control of collar rot of mint (Mint spp.) caused by Sclerotium rolfsii using biological means. Current Sci. 87: 362-366.

Someshwar, B., O.M. Bambawale, A.K. Tripathi, I. Ahmad and R.C. Srivastava. 2013. Biological Management of Fusarial Wilt of Tomato by Trichoderma spp. in Andamans. Indian J. Hort.. 70:397-403.

Srinon, W., K. Chuncheen, K. Jirattiwarutkul, K. Soytong and S. Kanokmedhakul. 2006. Efficacies of antagonistic fungi against Fusarium wilt disease of cucumber and tomato and the assay of its enzyme activity. J. Agric. and Technol. 2(2): 191-201.

Thakur, N. and A. Tripathi. 2015. Biological Management of Damping-Off, Buckeye Rot and Fusarial Wilt of Tomato (cv. Solan Lalima) under Mid-Hill Conditions of Himachal Pradesh. Agric. Sci. 6:535-544. http://dx.doi.org/10.4236/as.2015.65053.s

Zamanizadeh, H.R., N. Hatami, M.M. Aminaee and F. Rakhshandehroo.2011. Application of biofungicides in control of damping-off disease in greenhouse crops as a possible substitute to synthetic fungicides Int. J. Environ. Sci. Tech.8 (1), 129136. 
